WARSZTATY Z GEOGRAFII TURYZMU

ISBN 978-83-7969-138-8 $\quad$ s. $49-70$

http://dx.doi.org/10.18778/7969-138-8.05

Jolanta WOJCIECHOWSKA

Uniwersytet Łódzki

Irina PIROŻAK-DZIUK

Uniwersytet Łódzki

\title{
PARK ROMANTYCZNO-KRAJOBRAZOWY ZOFIÓWKA NA UKRAINIE JAKO PRZYKŁAD DOŚWIADCZEŃ POLSKICH TURYSTÓW I ORGANIZATORÓW TURYSTYKI KULTUROWEJ
}

\section{Wprowadzenie w problematykę badawczą}

Świat współczesny charakteryzuje dynamika przemian dawniej niespotykana, co ma bezpośredni wpływ na zmiany zachodzące w sferze szeroko rozumianych doświadczeń turystyczno-podróżniczych. Zmiany te powodują również, że coraz częściej i chętniej podejmowane są podróże nie tylko na zachód, ale również na wschód Europy i na inne kontynenty. A to wymaga przekraczania granic państwowych. Podróż do państw Europy Wschodniej wiąże się niestety z koniecznością załatwiania dokumentów granicznych, które mogą być traktowane jako utrudnienie. Nie mogą one jednak stać na przeszkodzie $\mathrm{w}$ poznawaniu ciekawych miejsc, jakże często nierozerwalnie związanych z kulturą i historią Polski.

Przez turystów dociekliwych - chętnych do doświadczania pogłębionego, do poszukiwania przeżyć niejako wyższego rzędu - coraz częściej jest podejmowana turystyka kulturowa. W ostatnich latach rozwija się ona intensywnie, czego dowodzą poświęcone jej dość liczne konferencje naukowe 
(m.in. KAZIMIERCZAK, red. 2012, WŁODARCZYK, KRAKOWIAK, red. 2012, KRAKOWIAK i in. 2013). Według Timothy'ego i Boyda (za: BUCZKOWSKA 2008), turystyka kulturowa to zagłębienie się $\mathrm{w}$ naturalną historię, dziedzictwo człowieka, sztukę, filozofię oraz instytucje (kulturalne) innego regionu lub kraju. Turystykę kulturową wyróżnia mnogość form realizowanych przez osoby o podobnych zainteresowaniach i często o zbliżonym poziomie intelektualnym. Wśród zróżnicowanych jej form A. Krzymowska-Kostrowicka (za: BUCZKOWSKA 2008) wyodrębnia np. turystykę historyczno-kulturową, która jest ukierunkowana na zapoznawanie się z zabytkami architektury i sztuki. Wspomniana autorka uważa, że formy turystyki kulturowej uprawiane przez turystów zwracają uwagę przede wszystkim na przedmiot ich zainteresowania.

Turystyka historyczno-kulturowa związana jest więc często z europejskimi szlakami kulturowymi, a wśród nich m.in. z parkami i ogrodami różnych typów. "Ogród” - jak zaznacza A. ZACHARIASZ (2006) - jest terminem szerszym i chronologicznie starszym od pojęcia "park". Jego pierwotne zastosowanie odnosiło się do układów geometrycznych. Natomiast „park” jest określeniem nowszym, które w XVIII w. zaczęto stosować do układów swobodnych. W XIX w. pojawiło się wiele różnych jego znaczeń, co wynikało m.in. $\mathrm{z}$ powiązania tego typu kompozycji z krajobrazem. $\mathrm{W} X \mathrm{X}$ w. termin ten został zastosowany także do parków narodowych i krajobrazowych, a więc skojarzono go z szeroko rozumianą ochroną, służącą celom naukowym, dydaktycznym, turystycznym i także estetycznym (ZACHARIASZ 2006). $Z$ analizowanymi terminami („ogród", „park") nierozerwalnie wiąże się pojęcie „krajobraz kulturowy”. W ujęciu architektury krajobrazu, rozumianej jako sztuka kształtowania przestrzeni na potrzeby człowieka - termin ten według J. WYRZYKOWSKIEGO (1991) - oznacza fizjonomię powierzchni Ziemi, będącą syntezą elementów przyrodniczych i działalności człowieka.

Dzieje polskich oraz ukraińskich parków i ogrodów często są powiązane w sposób nierozerwalny, ze względu na wspólną historię i kulturę obu państw. Fakt ten daje przesłanki do podejmowania podróży szlakami kulturowymi, które są interesujące tak dla polskich, jak i ukraińskich turystów. Dzięki podróżom człowiek poznaje współczesny świat, doświadcza go na różne sposoby. Na problematykę turystycznego doświadczania można więc spojrzeć z różnych perspektyw - socjologicznej, antropologicznej, ekonomicznej czy psychologicznej. Można ten proces analizować od strony turysty, a także kreatorów lub organizatorów turystyki. W literaturze przedmiotu nie ma zgodności co do definiowania tego pojęcia. Najczęściej traktuje 
się je jako element konsumpcji turystycznej (PRENTICE, WITT, HAMER 1998, URRY 1990), podczas której ważne są wrażenia wzrokowe, czyli patrzenie, oglądanie, ale nie tylko - także bodźce smakowe, zapachowe itp. Ten rodzaj doświadczeń powstałych wokół percepcji wzrokowej jest charakteryzowany w sposób niejednorodny, a wyrażane stanowiska są często opozycyjne względem siebie (MACCANNELL 2002, URRY 2007, WIECZORKIEWICZ 2008, PODEMSKI 2004).

Tak jak mamy do czynienia z doświadczeniami u turystów - czyli odczuciami, doznaniami, wiadomościami zdobytymi w wyniku obserwacji i przeżyć w trakcie odbywanej podróży - tak występują one również u kreatorów czy organizatorów turystyki, odpowiedzialnych za realizację takiej podróży. Zapewnienie turystom różnych form zakwaterowania i atrakcji nie obywa się bez zdobywania przez ich organizatorów doświadczeń w tym zakresie. Na zagadnienie doświadczeń turystycznych można więc spojrzeć od strony ich projektowania, a następnie zarządzania nimi. Można je także analizować w kontekście efektów ilościowych i jakościowych, wynikających ze zbioru działań oraz relacji i zachowań społecznych podejmowanych przez szeroko rozumianych uczestników turystyki.

W niniejszym opracowaniu zastosowano obydwa podejścia, czyli starano się przeanalizować doświadczenia turystów oraz organizatorów wyjazdów turystycznych w ramach turystyki kulturowej do obiektu, raczej mało znanego szerszemu gronu polskich turystów, jakim jest park romantyczno-krajobrazowy, zwany Zofiówką, położony w Humaniu na Ukrainie, związany z historią, kulturą i literaturą polską, mający wysoką wartość przyrodniczą oraz krajobrazową.

\section{Metodologia badań}

Problematyka pracy oscyluje wokół zagadnień związanych z turystyką kulturową oraz z jej doświadczaniem. Wybór obiektu do badań wyniknął z zainteresowań własnych jednej z autorek artykułu, będącej czynnym pilotem wycieczek do Rosji i Ukrainy. Omawiany obiekt był najpierw przedmiotem pracy dyplomowej obronionej na Podyplomowym Studium Turystyki Uniwersytetu Łódzkiego (PIROŻAK-DZIUK 2010), w której został zaprezentowany od strony walorów krajoznawczo-turystycznych. Następnie zainteresowania uzyskały bardziej sprofilowaną ścieżkę, gdyż w 2013 r. został opublikowany 
artykuł pokazujący ten obiekt jako produkt turystyczny dla polskich turystów funkcjonujący w ramach turystyki kulturowej (PIROŻAK-DZIUK, WOJCIECHOWSKA 2013).

Celem autorek niniejszego opracowania jest zaprezentowanie sposobów, rodzajów i form doświadczania przez turystów (w ramach odbywanych wycieczek autokarowych), a także przez organizatorów takiej turystyki na przykładzie parku Zofiówka jako produktu turystyki kulturowej znajdującego się obecnie poza granicami Polski, a związanego z dziedzictwem swoich przodków. Jako problem badawczy określono zidentyfikowanie doświadczeń wymienionych podmiotów w zakresie wybranego produktu turystycznego. Podjęta analiza została oparta na znajomości literatury fachowej (historycznej, kulturoznawczej, literaturoznawczej, turystycznej) oraz literatury pięknej, zarówno polskiej, jak i zagranicznej, a także na obserwacji uczestniczącej podmiotu i przedmiotu badań, prowadzonej od 2002 r. do chwili obecnej.

Opracowanie w jego analitycznej części można podzielić na cztery zagadnienia. Pierwsze dotyczy prezentacji parku jako atrakcji turystycznej, drugie - jego dostępności dla turystów polskich, trzecie zagadnienie odnosi się do kwestii doświadczania parku zarówno przez turystów, jak i organizatorów, a w części czwartej dąży się do teoretycznego ujęcia oferty parku w ramach produktu turystycznego. Niniejsza praca zawiera wybrane treści wspomnianych wcześniej opracowań oraz w dużej części została wzbogacona o nowe przemyślenia obu autorek.

\section{Park krajobrazowy Zofiówka jako atrakcja turystyczna}

Pełna i oficjalna nazwa obiektu będącego przedmiotem badań brzmi: Narodowy Dendrologiczny Park Zofiówka. W kwietniu 2005 r. nadano mu status Naukowo-Badawczego Instytutu Akademii Nauk Ukrainy w zakresie dendrologii (http://sofiyivka.org.ua). Położony jest na terenie miasta Humań znajdującego się w środkowej części Ukrainy, w obwodzie czerkaskim. Leży w północno-wschodniej części tego miasta, będącego siedzibą władz administracyjnych powiatu humańskiego, $\mathrm{u}$ zbiegu niewielkich rzek Kamionki i Umanki (dorzecze Bohu) i stanowi jego integralną część (rys. 1). 


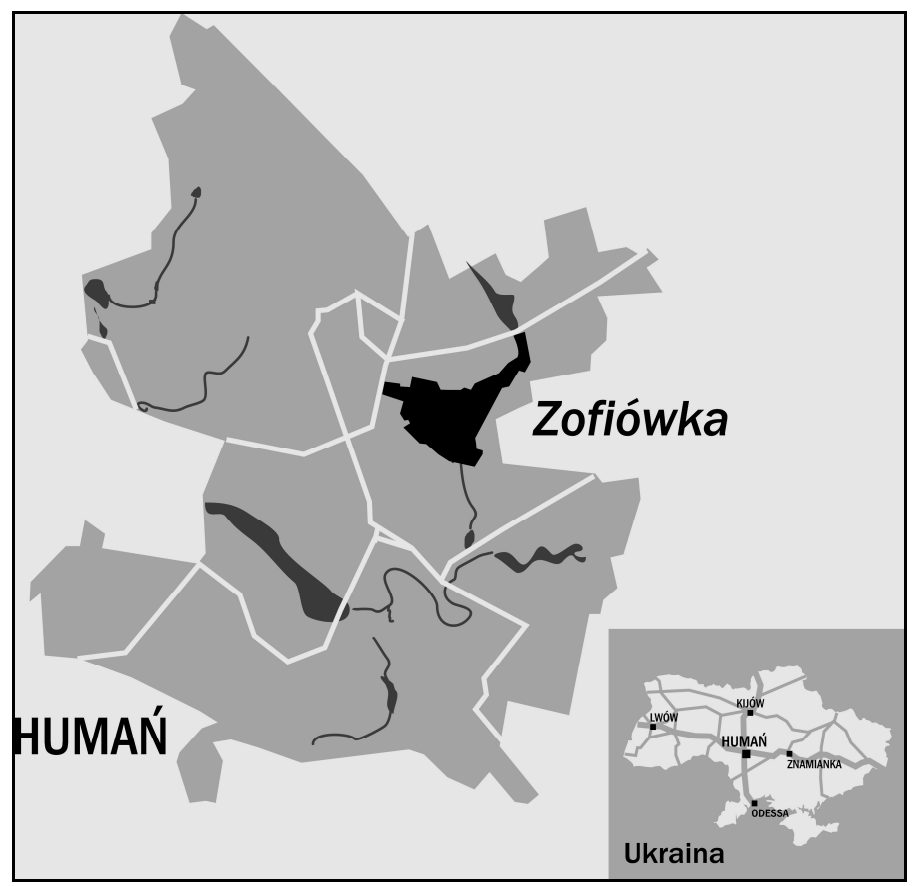

Rys. 1. Położenie parku Zofiówka na terenie miasta Humań Źródło: opracowanie własne ${ }^{1}$

Park został wybudowany w latach 1796-1802 przez Stanisława Szczęsnego Potockiego dla żony Zofii i nazwany na jej cześć „Sofijówka”. Pomysł budowy wyszedł od Zofii, która przebywając gościnnie w Nieborowie koło Warszawy u Heleny Radziwiłłowej zachwyciła się parkiem „Arkadia”. Stamtąd napisała list do Potockiego: "Zakochałam się w Arkadii do szaleństwa! Wiesz, że przy Twoich środkach można by było w ciągu dwóch lat mieć taką samą, a może i bardziej piękną Arkadię...".2 Warto zaznaczyć, że fortuna Potockich prawie nie miała sobie równej w całej Rzeczypospolitej, rodzina posiadała około 1,5 mln ha ziemi, a Franciszek Salezy Potocki (ojciec) nazywany był „małym królem Rusi” (KOZAK, BAJDA 2002). Stanisław Potocki postanowił urzeczywistnić marzenie ukochanej kobiety i w swoich posiadłościach $\mathrm{w}$ pobliżu Humania całą dolinę rzeki Kamionka, z malowniczymi wzgórzami oraz granitowymi skałami, zlecił przekształcić w ogromny park

\footnotetext{
${ }^{1}$ Wszystkie rysunki są opracowane graficznie przez Małgorzatę Michalską.

2 Tłumaczenie własne I. Pirożak-Dziuk - fragment listu Zofii Wittowej (CHRABAN, MiTIN 1990, s. 44-45).
} 
angielski oraz wyposażyć go w wiele kaskad i fontann. Według V. MiTiNA (1990) park ten miał dorównywać ogrodom Wschodu. Zamierzeniem Potockiego było, aby park nie tylko był najpiękniejszy, ale i największy w Europie - godny tej, której został poświęcony. Należy dodać za J. ŁOJKIEM (1972), że Zofia - z pochodzenia Greczynka - była zjawiskowo piękną kobietą.

Autorem projektu, a także kierownikiem wszystkich prac dotyczących budowy parku został inżynier Ludwik Metzel, który całość (ponad 150 ha) skomponował przestrzennie w stylu romantycznym. Podstawą kompozycyjnego układu centralnej części parku były idee i wzory zaczerpnięte $\mathrm{z}$ bogatej symboliki mitologii greckiej i rzymskiej. Znalazły one swój wyraz w różnego rodzaju dziełach architektonicznych, których na terenie parku rozmieszczono około 60. Były to m.in. rzeźby z włoskich pracowni oraz sztuczne groty, altany, obeliski itp. Warto nadmienić, że w parku stały autentyczne rzeźby greckie, znalezione $\mathrm{w}$ rejonie wykopalisk starożytnego Chersonezu znajdującego się na Krymie. Jedna - przedstawiająca Eurypidesa - jest jedyną w świecie statuą dramatopisarza, która zachowała się do naszych czasów (KOSENKO 2003). Na terenie parku wykopano ponadto dwa wielkie sztuczne stawy (dolny i górny), które połączono kaskadą rzeki Kamionki. Pod ziemią oba stawy łączył kanał ze śluzą, którędy do dnia dzisiejszego pływają łodzie $\mathrm{z}$ turystami. Na Dolnym Stawie utworzono wyspę o owalnym kształcie z usytuowaną na niej świątynią Posejdona. Równolegle z pracami budowlanymi prowadzono sadzenie wielu gatunków rodzimych drzew oraz rzadkich roślin egzotycznych (np. sprowadzanych z Atlasu i Libanu). Budowa centralnej części parku została zakończona przed majem 1802 r. Uroczyste jego otwarcie przypuszczalnie odbyło się z okazji imienin Zofii (CHRABAN, MITIN 1990). Dalsza budowa parku została przerwana nagła śmiercią Potockiego (marzec 1805 r.). Zamierzonych przez niego koncepcji nikt nie był w stanie urzeczywistnić, a to, co już zostało zbudowane, od razu otrzymało powszechne uznanie jako arcydzieło sztuki ogrodowej (CHRABAN, MITIN 1990).

Na przestrzeni stuleci wiele się jednak w parku zmieniało, historia wyraźnie odcisnęła swoje piętno. Za udział Aleksandra Potockiego (syna Stanisława) w powstaniu listopadowym park został skonfiskowany przez cara Mikołaja I. Najpierw został przekazany Izbie Państwowej w Kijowie, następnie Ministerstwu Wojskowości, później Głównej Szkole Ogrodnictwa, a w wieku XX nadano mu status parku narodowego ${ }^{3}$ (1929 r.). W latach 90.

\footnotetext{
${ }^{3}$ W języku ukraińskim „Zapowidnyk”.
} 
XX w. został samodzielną jednostką naukową Akademii Nauk Ukrainy (KOSENKO 2003). Pomimo że na jego utrzymanie, restauracje i rozbudowy przeznaczano $w$ różnych okresach znaczące kwoty, wiele jednak utracił ze swego pierwotnego blasku, głównie $\mathrm{z}$ uwagi na zawieruchy wojenne oraz polityczno-ekonomiczne zmiany mające miejsce $\mathrm{w} X X \mathrm{w}$. Nie bez znaczenia jest także wpływ naturalnego procesu niszczenia oraz degradacji na skutek kataklizmów przyrodniczych, np. powodzi. Obecnie jest utrzymany w dobrym stanie oraz jest odwiedzany przez turystów.

Współcześnie w parku można wyróżnić trzy główne jego części, które powstały w różnych okresach historycznych (rys. 2). Część centralna, najstarsza prezentuje pierwszy okres budowy parku oraz jego rozbudowy w pierwszej połowie XIX w. Część północno-wschodnia powstała pod koniec XIX w., kiedy utworzono tzw. park angielski i arboretum. Natomiast część zachodnia jest najmłodsza, gdyż urządzono ją w latach 90. XX w. Tutaj na obszarze 53 ha urządzono nową strefę krajobrazową - tzw. Nowy Park, na terenie której wybudowano trzy sztuczne stawy, alpinarium oraz zasadzono wiele rzadkich gatunków drzew i krzewów. W tej części prowadzone są badania naukowe $\mathrm{w}$ zakresie bioekologicznego stanu introdukcji roślin (KOSENKO 2007). W latach 90. XX w. teren parku został powiększony dzięki dołączeniu do jego zachodniej części ponad 10 ha pobliskiego jaru. Obecnie obszar Zofiówki wynosi około 170 ha.

Dodatkową osobliwością parku są ciągi komunikacyjne, które prezentują tu dwie kategorie: szerokich alei, prowadzących do najważniejszych obiektów usytuowanych w centralnej części oraz swobodnie rozmieszczonych ścieżek. Większość alei ma swoje nazwy. Aleja Główna wiedzie do Dolnego Stawu, Aleja Dolna obiega wymieniony staw, prowadząc do tarasów widokowych, z których można obserwować wiele ciekawych wnętrz krajobrazowych, a Górna prowadzi do Zwierzyńca ${ }^{4}$. Ścieżki prowadzą zwiedzających również do celowo zaprojektowanych miejsc widokowych oraz krajobrazowych wnętrz. Szczególnie cenne i atrakcyjne dla zwiedzającego są kontrastowość form, zmienność krajobrazów i naturalnych wnętrz, które kreują grupy drzew, gaje, laski, kępy oraz ściany zwartego lasu. Drzewa i rośliny egzotyczne, a także wyhodowane w Zofiówce nowe gatunki i odmiany uatrakcyjniają rodzimy zestaw roślin. Dodatkową i bardzo poznawczą atrakcją $\mathrm{w}$ trakcie poruszania się po swobodnym układzie parku jest możliwość obserwacji bogatej fauny, zachowanej tu zgodnie z zasadami ekologii.

${ }^{4}$ W Zwierzyńcu do 1854 r. trzymano dzikie zwierzęta (KOSENKO 1990). 


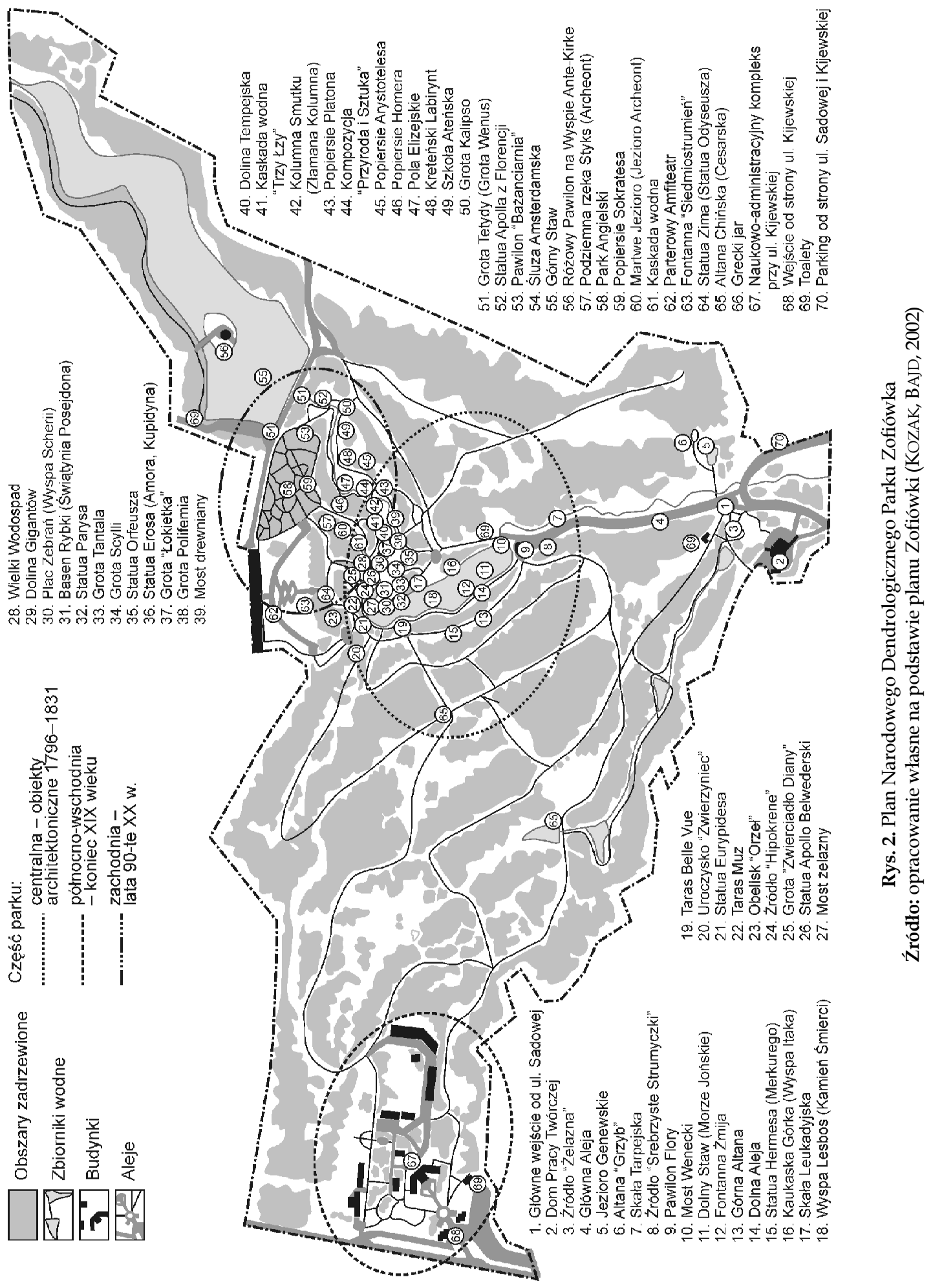


Największym zainteresowaniem turystów cieszy się centralna (historyczna) część, w której można zaobserwować wiele zabytkowych obiektów, $\mathrm{w}$ tym pochodzących $\mathrm{z}$ czasów Potockich. $\mathrm{Z}$ tego okresu prawie $\mathrm{w}$ niezmienionym stanie zostało zachowane ukształtowanie terenu oraz system wodny. Natomiast z rzeźb stojących na pierwotnym miejscu jest tylko jedna dwumetrowy posąg Eurypidesa, postawiony w 1800 r. (fot. 1). Wizytówką parku jest Pawilon Flory (wybudowany w 1851 r.), do którego prowadzi Aleja Główna. Pawilon prezentuje się okazale, a zarazem wytwornie, dzięki wysokim kolumnom $\mathrm{w}$ doryckim stylu i misternemu fryzowi. W prześwitach kolumn można obserwować panoramę Dolnego Stawu (wybudowanego w 1802 r.). Po środku jego lustrzanej powierzchni umieszczono fontannę, z której bije do $18 \mathrm{~m}$ wysokości woda z szeroko otwartej paszczy wijącej się żmii (fontanna powstała w 1851 r.) (fot. 2). Na układ przestrzenny wokó1 Dolnego Stawu składają się rośliny, kamienie, woda, architektura dużych i małych form oraz kompleks urządzeń hydrotechnicznych, co razem daje wyjątkową wartość krajobrazową.

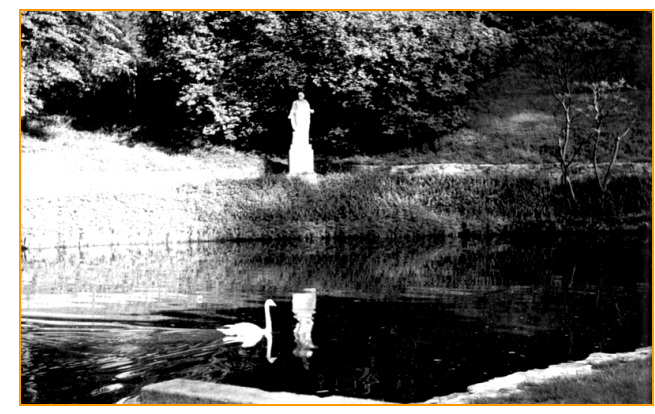

Fot. 1. Statua Eurypidesa Źródło: Tatiana Pirożak

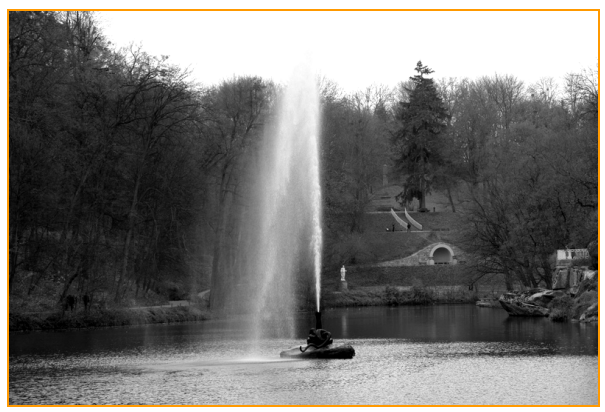

Fot. 2. Fontanna Żmija na Dolnym Stawie Źródło: Tatiana Pirożak

Do obiektów parku mających dużą wartość przyrodniczo-historyczną należy zaliczyć: Skałę Leukadyjską, Wyspę Scherii, groty: Zwierciadło Diany, Tantala i Łokietek oraz Taras Muz (inaczej Góra Parnas). Na wzgórzu nad Dolnym Stawem znajduje się taras widokowy zwany Belle Vue (Piękny Widok), z którego można obserwować Wyspę Scherii, Wielki Wodospad, Dolinę Gigantów i inne ciekawe miejsca. Wielki Wodospad, mający $15 \mathrm{~m}$ wysokości, stanowi jedną z większych atrakcji turystycznych parku (KOSENKO 1990). Urządzono pod nim tunel prowadzący do alei biegnącej wzdłuż krawędzi naturalnej skały. Spacer tą aleją dostarcza wiele emocji oraz este- 
tycznych wrażeń. Warto nadmienić, że poruszając się alejami parku zwiedzający ujrzą wiele rzeźb, wśród których najbardziej cennymi są statuy: Parysa (1. poł. XIX w.), Odyseusza (1800) i wspomniany wcześniej posąg Eurypidesa. Za wyjątkowe atrakcje uznaje się także: Grotę Tetydy (1802 r.) ze statuą Wenus, usytuowaną na Polach Elizejskich, oraz Górny Staw z Amsterdamską Śluzą (1802 r.) i Pawilonem Różowym (1847 r.) na Wyspie AntyKirke (1802 r.) (fot. 3). W Grocie Tetydy można obejrzeć granitowe kolumny, dekoracyjną arkę i kaskadę granitowych, monolitowych schodków, po których (tak jak 200 lat wcześniej) przelewa i mieni się kolorami tęczy wodny potok.

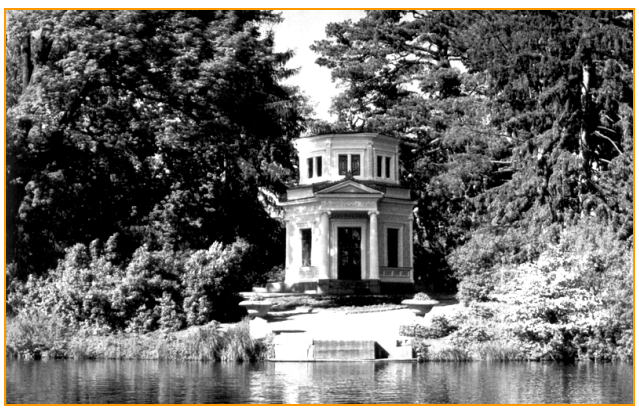

Fot. 3. Pawilon Różowy na Wyspie Anty-Kirke Źródło: Tatiana Pirożak

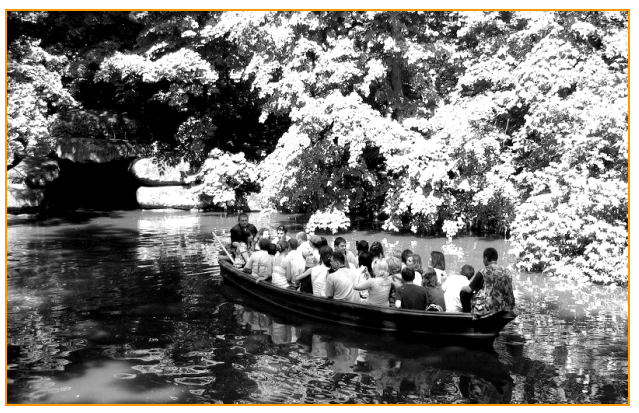

Fot. 4. Wpłynięcie do podziemnej rzeki Styks Źródło: Maria Nowakowska

Park Zofiówka prezentuje atrakcję turystyczną wysokiej rangi, która przyciąga uwagę turystów zróżnicowanymi walorami zarówno przyrodniczymi, krajobrazowymi, architektonicznymi, jak i kulturowymi, a także ich odpowiednim przystosowaniem do zwiedzania. Spośród bardzo wielu atrakcji oferowanych przez park turyści (również polscy) najczęściej wskazują na obfitującą $\mathrm{w}$ wiele wrażeń wycieczkę łodziami podziemną rzeką Acheront (Styks) o długości 223 m (fot. 4).

\section{Dostępność parku Zofiówka dla turystów}

Rozważania warto zacząć od analizy dostępności komunikacyjnej miasta Humań. Przyglądając się jego położeniu na mapie Ukrainy widać, że leży dokładnie w jej centrum, na skrzyżowaniu ważnych dróg krajowych i europejskich (rys. 3). 


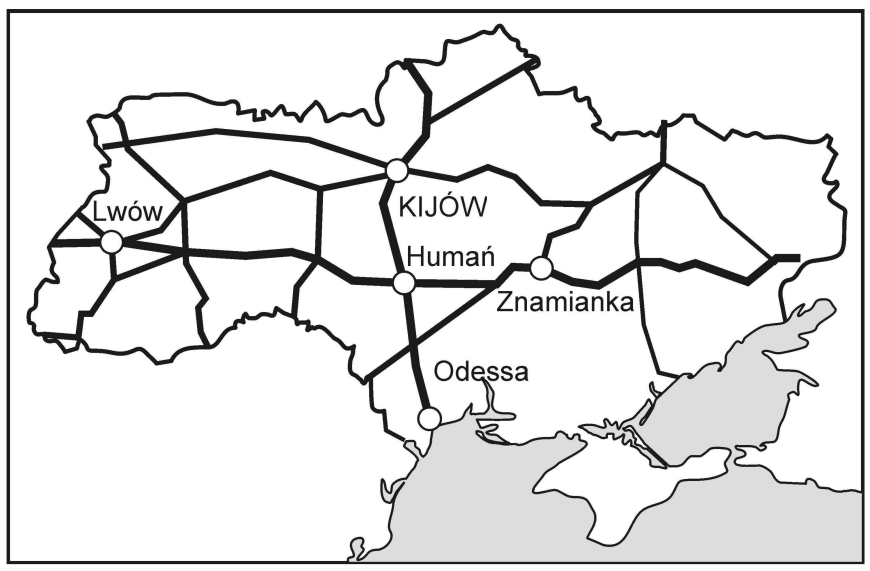

Rys. 3. Położenie miasta Humań na mapie Ukrainy Źródło: opracowanie własne

W pobliżu miasta przebiega z północy na południe droga kołowa nr M05 (o znaczeniu międzynarodowym Kijów-Odessa), będąca częścią trasy europejskiej E95. Jest to nowoczesna autostrada, którą także kursują autobusy komunikacji krajowej i lokalnej. Ze Lwowa przez Tarnopol i Winnicę prowadzi do Humania droga M12 (międzynarodowa), będąca częścią trasy europejskiej E50. Poza nielicznymi fragmentami jest to droga jednojezdniowa. Do Humania najczęściej tą drogą przybywają polscy turyści, niejednokrotnie podążający dalej, do Odessy lub na Krym. Droga ta, w opinii Polaków, raczej nie jest dobrej jakości. Trzeba nadmienić, że miasto leży na uboczu głównych linii kolejowych. Najbliższa stacja kolejowa znajduje się w odległości 22 km od Humania, w miejscowości Chrystyniwka.

Humań jest miastem liczącym około 87 tys. mieszkańców. Prawa miejskie ma od 1795 r. Znajduje się tu kilka szkół wyższych, rozwija się przemysł maszynowy, metalowy, spożywczy oraz lekki. Oprócz Zofiówki turyści mogą zobaczyć miejscowe muzeum, kościół z drugiej poł. XIX w. i halę targową z XVIII w. (encyklopedia.pwn.pl). Najważniejszym jednak celem przyjazdów turystycznych jest omawiany park. Turyści przybywają do niego najczęściej w grupach zorganizowanych po to, aby poznać jego atrakcje przyrodnicze i kulturowe. Ponadto w parku są organizowane imprezy kulturalne, a w obiektach stałych odbywają się różnorodne konferencje, sympozja lub naukowe seminaria. Różnorodnym formom turystyki sprzyjają nie tylko zabytki kultury oraz obiekty przyrody, ale także istniejąca tu infrastruktura 
techniczna wraz z zapleczem gospodarczym oraz urządzeniami turystycznymi, bazą gastronomiczną i noclegową.

Na terenie miasta dojazd do parku jest dobrze oznakowany. Od jego granic przy drogach kołowych umieszczono dostateczną liczbę tablic informacyjnych w językach: ukraińskim i angielskim. Do parku prowadzą dwa wejścia - od zachodu (ul. Kijewska) i południa (ul. Sadowa). W pobliżu głównej bramy wejściowej (przy ul. Sadowej) usytuowany jest parking dla samochodów osobowych i autokarów. Parking ma asfaltową nawierzchnię i jest przeznaczony dla co najmniej 30 autokarów. Drugi parking mieści się przy wejściu do parku od strony zachodniej, przy ulicy Kijewskiej. Może on pomieścić dość dużą liczbę pojazdów osobowych oraz około 50 pojazdów autokarowych. W jego bliskim otoczeniu funkcjonuje kawiarnia na 30 miejsc oraz sklepy z pamiątkami o nazwach: „Flora Zofiówki” i „Akwanarium”. Jak same nazwy wskazują, oferują one przede wszystkim pamiątki przyrodnicze, takie np. jak: dekoracyjne rośliny lub sadzonki rzadkich krzewów. Właśnie $\mathrm{z}$ tego drugiego parkingu rozpoczyna się oprowadzanie wycieczek po tzw. Nowym Parku, gdzie turyści uzyskują informacje dotyczące świata roślin. Dopiero potem docierają do głównego wejścia (od strony ul. Sadowej), aby zgodnie $\mathrm{z}$ wyznaczoną $\mathrm{w}$ terenie marszrutą poznać walory historyczno-kulturowe Zofiówki.

Tablica informacyjna umieszczona przy głównej alei przedstawia szczegółowy plan Parku, na którym zaznaczono trasę turystyczną główną i łącznikowe. Napisy na niej są w języku rosyjskim, natomiast przy wejściu można otrzymać plan Zofiówki w języku angielskim. Poza tym na terenie Parku umieszczone są tablice pokazujące kierunek marszruty oraz kierunkowskazy prowadzące do wyjścia. Stanowią one dużą pomoc dla turystów, zwłaszcza będących tam po raz pierwszy. W arboretum na terenie parku angielskiego (1891) znajdują się dwujęzyczne tablice (w języku rosyjskim oraz po łacinie), zawierające podstawowe informacje o roślinach. Należy nadmienić, że oprowadzanie wycieczek po parku odbywa się w sześciu językach, w tym w języku polskim.

Na terenie parku jest dużo miejsc, w których można odpocząć, posiedzieć i podziwiać piękne widoki. Temu służą m.in. stylizowane ławki, wykonane na wzór tych, które znajdowały się przed 1917 r., a zostały zrekonstruowane na podstawie fotografii z $1900 \mathrm{r}$. Ławki usytuowane są przede wszystkim w rejonie Wyspy Scherii, Górnego Stawu, Parterowego Amfiteatru, na tarasie widokowym Belle Vue. W grotach znajdują się ławy wyciosane w granicie, które służyły odwiedzającym już w XIX w. Ponadto zwracają 
uwagę inne techniczne drobiazgi, jak: stylizowane kosze na śmieci, lampy oświetleniowe, źródełka z wodą mineralną. Toalety zlokalizowane są przy wejściach do parku (od ul. Sadowej i ul. Kijewskiej) oraz w pobliżu stawów (Dolnego i Górnego). Park umożliwia odpoczynek i rekreację wszystkim grupom wiekowym. W ostatnich latach znacznie poszerzono wachlarz usług dla odwiedzających, proponując dodatkowe atrakcje, typu: jazda konna, przejażdżki karetą i przeprawa promem na Wyspę Anty-Kirke. Warto podkreślić, że w kilku miejscach na terenie parku (nie tylko przy głównym wejściu) można zakupić pamiątki, takie jak: widokówki, foldery, broszury oraz książki o Zofiówce (w tym monografie naukowe) oraz różnego rodzaju drobiazgi, głównie breloczki, kubki itp.

Park dysponuje dwoma kompleksami hotelowymi, usytuowanymi w pobliżu głównego wejścia, czyli od ulic Sadowej oraz od Kijewskiej. Ten od ulicy Sadowej został zbudowany w 1998 r. i nosi nazwę "Dom Pracy Uczonych". W jego skład wchodzą: hotel na 45 miejsc z salą konferencyjną, ogród zimowy z ekspozycją rzeźb przeniesionych z pleneru, sauna, płatny parking oraz restauracja na 100 miejsc konsumpcyjnych (fot. 5). Drugi kompleks (przy ul. Kijewskiej), wybudowany także w latach 90. XX w., zawiera przede wszystkim obiekty przeznaczone do celów naukowo-administracyjnych, takie jak: sale wykładowe, laboratorium mikroklonowania, salę konferencyjną na 200 miejsc oraz Muzeum Historii Zofiówki. Poza tym na jego terenie otworzono w 2007 r. hotel "Sofijski” na 65 miejsc noclegowych (fot. 6). Według danych udostępnianych przez administrację parku corocznie odwiedza go blisko 500 tys. osób, wśród których 29\% stanowią cudzoziemcy (http:// thebestvoyage.ru/unikalnyj-dendropark-sofievka/).

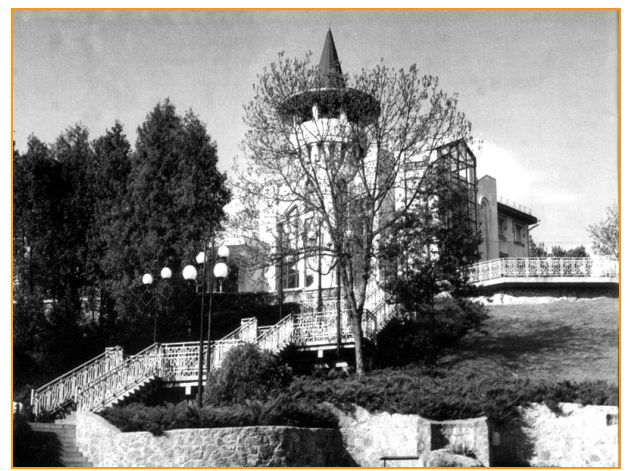

Fot. 5. Kompleks hotelowy „Dom Pracy Uczonych" Źródło: Michaił Kozak

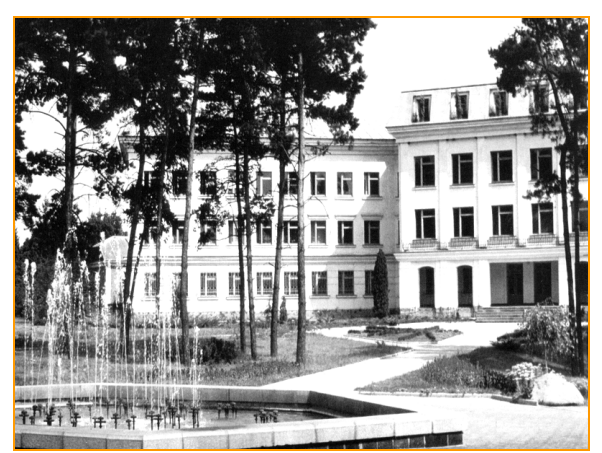

Fot. 6. Hotel Sofijski Źródło: Michaił Kozak 
Reasumując przedstawione zagadnienie należy stwierdzić, że dostępność Parku Zofiówka dla turystów jest dobra. W przypadku większości analizowanych elementów spełnia on podstawowe wymogi, a dla wielu przekracza podstawowy standard. Trzeba też podkreślić, że omawiany obiekt umożliwia turystom krajowym i zagranicznym realizowanie celu poznawczego, kształcącego, rekreacyjnego i pobytowego. Zapewnia im także dodatkowe atrakcje - zakup pamiątek, uczestnictwo w ogólnie dostępnych, jak i zamkniętych imprezach. Jest więc rozpoznawalny jako zbiór walorów funkcjonalnych, materialnych i niematerialnych oraz psychologicznych, pozwalający na zaspokojenie oczekiwań konsumentów, co upoważnia do określenia go produktem turystycznym (WALAS 2001).

\section{Sylwetka polskiego turysty i doświadczanie przez niego parku Zofiówka}

Warto nakreślić sylwetkę polskiego turysty wyjeżdżającego na Ukrainę w oparciu o prowadzone bezpośrednie obserwacje (uczestniczące, niejawne). Bagaż ponad 10-letnich doświadczeń w pilotażu wycieczek upoważnia do podzielenia się spostrzeżeniami w tym zakresie.

W wycieczkach biorą udział turyści będący przeważnie w wieku od 40 do 65 roku życia. Są to więc osoby dojrzałe oraz w starszym wieku. Rzadko wyjeżdżają osoby młode, liczące poniżej 30 lat. Uczestniczą one ewentualnie wtedy, jeżeli wycieczka prowadzi na Krym. Dominują kobiety, stanowiące nawet $65 \%$ ogółu uczestników wyjazdu. Turyści ci stanowią więc dość homogeniczną grupę i prezentują, zgodnie z określeniem M. BANASZKIEWICZ (2012), typ turystów "średniokulturowych". Autorka nie definiuje tego terminu, jednak można się domyślić, że są to turyści, którzy nie wykazują zbyt dużych chęci do zdobywania wiedzy w określonej dziedzinie. Często zaspokajają się informacjami wyłącznie uzyskanymi podczas wycieczki, co ich zdaniem już pozwala oświetlić sobie kolejny fragment rzeczywistości. A ,im jaśniej dookoła, tym łatwiej dostrzec inność, która nie przestaje być obca, staje się bardziej zrozumiała" (BANASZKIEWICZ 2012, s. 317).

Jednym z motywów uczestnictwa w wyjeździe, najczęściej wskazywanym w wywiadach swobodnych, jest chęć poznania miejsc autentycznych oraz mniej skomercjalizowanych od tych, które spotyka się na południu 
i zachodzie Europy. Opisywani turyści cenią sobie możliwość bezpośredniego kontaktu z tubylcami, z którymi próbują się porozumieć, najczęściej po rosyjsku, bez pomocy pilota tłumacza. Podejmowane przez nich tego typu relacje są przykładem tzw. dialogu ewentualnie kontaktu międzykulturowego. J. WYSOKIŃSKI (2005) dialog międzykulturowy rozumie jako spotkanie przedstawicieli różnych narodów, kultur, religii. Ma on - według tego autora - wartość nie do zastąpienia, ponieważ przewiduje kontakt osobisty, bezpośredni oraz sprzyja pozbywaniu się stereotypów.

Uwzględniając powyższe spostrzeżenia można powiedzieć, że opisana grupa w dużym stopniu wykazuje podobieństwa do turystów wyjeżdżających do Sankt Petersburga, szczegółowo badanych przez M. BANASZKIEWICZ (2012). Pomijając charakterystykę demograficzną, trzeba zaznaczyć, że każdy pilot ma własną klasyfikację turystów, która wynika z przebiegu wycieczki.

Typowe wycieczki polskie w Humaniu przeznaczają na zwiedzanie Zofiówki przeważnie około 2,5 do 3 godzin. W tym jest wliczony czas wolny. Zwiedzanie, ze względu na dość ograniczony czas, jest skoncentrowane wyłącznie na jego centralnej (tj. historycznej) części. Oprowadzanie odbywa się przez przewodników zamawianych w kasie parku, który współpracuje z trzema przewodnikami mówiącymi w języku polskim. Jednak ze względu na konieczność opłaty przewodnika ze znajomością języka obcego, biura polskie wybierają często tańszy wariant, czyli tłumaczenie pilota za przewodnikiem mówiącym w językach: ukrainskim bądź rosyjskim. Wówczas tłumaczenie zabiera dodatkowy czas, który mógłby być poświęcony na indywidualne zwiedzanie.

Nawet przy tak krótkim i w pewnym sensie powierzchownym zwiedzaniu parku, polscy turyści prezentują niezwykłe zainteresowanie obiektem, jego historią i walorami krajobrazowymi, na co też zwracają uwage przewodnicy oprowadzający wycieczki polskie. Często, już po opuszczeniu Zofiówki, turyści w autokarze wymieniają się opiniami, mówią o niedosycie, który czują po zwiedzaniu. Wielu stwierdza, że nigdy wcześniej nie słyszeli o tym obiekcie bądź mieli nader skromną o nim wiedzę, zaczerpniętą z Internetu tuż przed wyjazdem. Wielokrotnie podkreślają, że Zofiówka jest obiektem mało rozreklamowanym w Polsce, a wartym polecenia, by go bliżej poznać. Nigdy nie zaobserwowano, aby ze strony polskich turystów padły negatywne bądź krytyczne uwagi pod kątem infrastruktury obiektu czy wiedzy i kultury osobistej ukraińskich przewodników. Turyści zadają przewodnikom bardzo różne pytania, wynikające $\mathrm{z}$ ich zainteresowań, ale także ze zwykłej ciekawości. Często dotyczą one życia prywatnego Stanisława Sz. Potockiego, 
historii jego miłości do Zofii Wittowej oraz ostatnich lat życia Stanisława Trembeckiego, pochowanego w Humaniu. Czasem padają też pytania, jak jest postrzegana w Humaniu postać Potockiego? Warto tutaj zaznaczyć, że założyciel i fundator parku Stanisław Szczęsny Potocki był kontrowersyjną postacią w historii I Rzeczpospolitej. Będąc marszałkiem konfederacji targowickiej, przez jednych jednoznacznie był uważany za zdrajcę Rzeczpospolitej, przez innych za człowieka, którego postawa nie była pozbawiona sensu w określonym momencie historyczno-politycznym (ŁOJEK 1988).

Podsumowując zaprezentowane zagadnienie trzeba podkreślić, że dla polskich turystów omawiany park jest dziedzictwem własnych przodków, znajdującym się poza granicami kraju. Ważne jest więc w jakim stopniu utożsamiają się oni z tym dziedzictwem oraz jaką wiedzę na jego temat mają lub mieć będą. Można określić, że spektrum doświadczeń polskich turystów ma przede wszystkim tło dziedzictwa historycznego i kulturowego.

\section{O doświadczaniu parku Zofiówka przez kreatorów turystyki zorganizowanej}

Z punktu widzenia organizatora turystyki można wyrazić żal lub wręcz niezadowolenie, że przy napiętym programie zwiedzania nie ma możliwości zwrócenia uwagi turystów na szersze „wątki polskie”, np. związane z literaturą piękną czy ze znanymi postaciami, w życiu bądź twórczości, których park odegrał znaczącą rolę. Niemniej uznaje się, że oferta turystyczna tego obiektu - sprzedawana niejako w "pigułce" - może jednak rozbudzić w turyście chęć bliższego poznania. Warto więc zaprezentować przykładowy program wycieczki autokarowej na Ukrainę odnoszący się do dnia, w którym przewidziane jest zwiedzanie parku Zofiówka.

Wycieczka nosi nazwę „Szlakiem Magnackich Rezydencji Rodu Potockich na Ukrainie" i prowadzi przez Lwów, Tulczyn, Humań i Odessę. Należy zaznaczyć, że bez wątpienia problemem takiej wycieczki są duże odległości, które w ciągu każdego dnia należy pokonać. Odległość Zofiówki od granicy polskiej wynosi około $615 \mathrm{~km}$. Przy pozostawiającym wiele do życzenia stanie dróg na trasie Lwów - Chmielnicki - Winnica - Humań, trzeba planować nocleg we Lwowie. W programie zwiedzania Lwowa znajduje się również obiekt rodu Potockich. Jest to dawny pałac, w którym obecnie mieś- 
ci się rezydencja prezydenta Ukrainy oraz Lwowska Galeria Sztuki. Po wyjeździe wczesnym rankiem ze Lwowa, po południu można dotrzeć do Tulczyna - kolejnej rodowej rezydencji Potockich, oddalonej około $410 \mathrm{~km}$ od Lwowa. Po zwiedzeniu pałacu w Tulczynie następuje przejazd do Humania na nocleg (ok. $120 \mathrm{~km}$ ). Z miejsc noclegowych oferowanych w Humaniu warto wymienić obiekty znajdujące się na terenie parku Zofiówka, czyli hotel „Sofijski” oraz „Dom Pracy Uczonych”. Hotele na terenie miasta prezentują raczej niski poziom usług. Smaczne i dobrej jakości dania kuchni regionalnej można zamówić albo w restauracji hotelu wchodzącego w skład kompleksu hotelowo-konferencyjnego „Dom Pracy Uczonych” lub w obiektach restauracyjnych na terenie miasta, gdzie można polecić „Szynok Kadubok" .

Następnego dnia od rana jest zwiedzanie historycznej części Zofiówki, wraz z atrakcją przepłynięcia łodziami podziemną rzeką, oraz zapoznanie się z nową strefą krajobrazową Parku w zachodniej jego części. Po obiedzie (ok. godz. 15-16) następuje wyjazd do Odessy na nocleg (ok. 265 km). W program zwiedzania Odessy jest włączony również pałac Potockich - obecnie Galeria Malarstwa Rosyjskiego i Ukraińskiego.

Aby móc poświęcić więcej czasu na zwiedzanie Zofiówki, można wybrać inny wariant trasy, która prowadzi przez Łuck i Żytomierz do Kijowa. Droga od granicy polskiej do Kijowa została zmodernizowana na mistrzostwa piłki nożnej Euro 2012 i podróż nią nie jest męcząca, ponadto daje możliwość zwiedzenia Kijowa. Jak zaznaczono wcześniej, z Kijowa do Humania prowadzi autostrada i podróż zajmuje niecałe 2,5 godziny.

$\mathrm{Z}$ punktu widzenia organizatora opisanych tras wycieczek jego marzeniem jest, aby zawierały one w programie co najmniej dwudniowy pobyt w Zofiówce. Marzenia są po to, aby je realizować, a w trakcie ich urzeczywistniania trzeba pamiętać, że turystyka kulturowa stanowi specyficzną formę turystyki, przeznaczoną dla określonej grupy odbiorców, poszukujących różnych sposobów zaspokajania swoich szczególnych zainteresowań.

\section{Park Zofiówka jako produkt turystyki kulturowej}

Jednym z ważniejszych motywów pobudzających turystów do uprawiania turystyki kulturowej jest zainteresowanie wybranym konkretnym zagadnieniem. Opisywany Park zasługuje więc na szczególną uwagę turystów, 
gdyż daje im możliwości uprawiania na jego terenie turystyki kulturowej w różnych specjalistycznych odmianach. Na rys. 4 pokazano najważniejsze rodzaje tej turystyki, które można wyodrębnić z punktu widzenia polskich turystów na podstawie oferty parku. Są to następujące rodzaje turystyki: śladami polskich historycznych parków i ogrodów, epok i stylów w sztuce, stylów w sztuce ogrodowej, literacka i biograficzna.

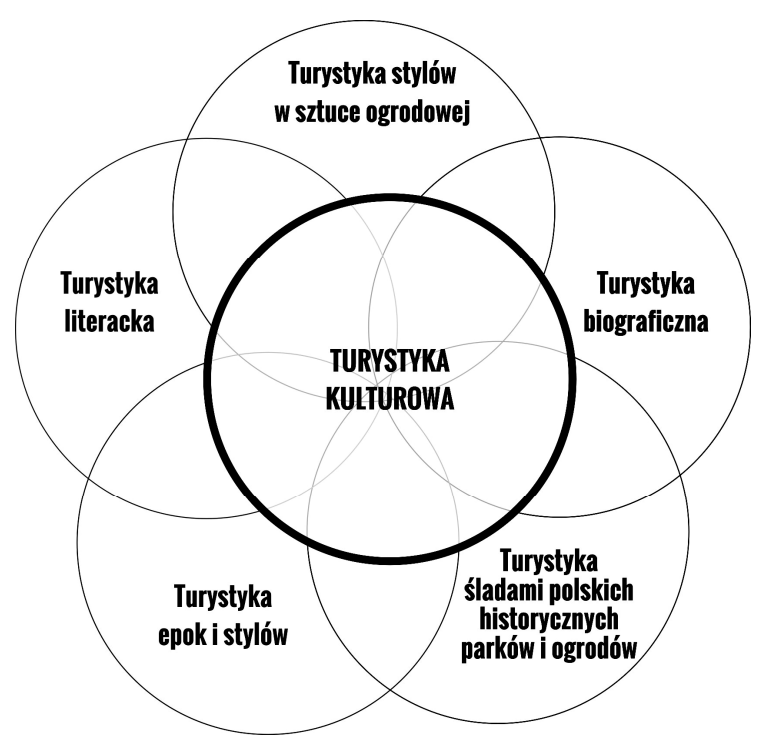

Rys. 4. Ważniejsze rodzaje turystyki kulturowej uprawiane przez polskich turystów na terenie parku Zofiówka Źródło: opracowanie własne

Należy podkreślić, iż wydzielone typy, mimo że różnią się od siebie swymi zasadniczymi celami i funkcjami, często jednak przenikają się wzajemnie oraz tematycznie nakładają się $w$ tym samym miejscu i czasie. Fakt ten wyraźnie ilustruje rys. 4, a w literaturze zwrócili na to uwagę m.in. W. KOSIŃSKI, P. BYRSKI, P. KOWALSKI (2008). Każda z wyróżnionych form ma więc swój własny zakres, ale jednocześnie dzieli w mniejszym lub większym stopniu wspólny z pozostałymi rodzajami turystyki. Poprzez zaproponowany układ wydzielonych typów turystyki kulturowej na rys. 4 starano się uwypuklić ich wspólne zakresy, zwłaszcza w przypadku tych form, których nazwy najmniej wskazują na takie relacje. Na przykład „turystyka epok i sty- 
lów w sztuce" w dużym stopniu nawiązuje do formy „turystyka biograficzna", ale tego jej zakresu, który bardziej dotyczy dzieł wybranego artysty bądź architekta, aniżeli jego życia. Można więc powiedzieć, że ten wspólny zakres wymienionych przykładowo dwóch rodzajów turystyki kulturowej rodzi niejako kolejną jej formę, którą można nazwać za K. BUCZKOWSKĄ (2008) - „turystyka w celu poznania dzieł wybitnych twórców”.

Celowe umieszczenie na rysunku dwóch form: "turystyka biograficzna” i „turystyka literacka" w położeniu niejako lustrzanym ma przede wszystkim pokazać ich wspólne zakresy z lokalizowanymi „po sąsiedzku” rodzajami turystyki kulturowej. Według K. Buczkowskiej „turystyka biograficzna” to odwiedzanie miejsc związanych z życiem i działalnością ludzi - jednostek wybitnych, znaczących czy bliskich szerszemu gronu odbiorców, a także znanych tylko wybranym kręgom kulturowym. Zdaniem tej autorki zainteresowaniem cieszą się zarówno miejsca odnoszące się do różnych postaci żyjących, jak i nieżyjących, czy też osób lubianych lub potępianych (BUCZKOWSKA 2008). Zgodnie natomiast z poglądem P. Zmyślonego (za: BuCZKOWSKA 2008), turystyka literacka obejmuje wszystkie czynności towarzyszące czasowemu przemieszczaniu się osób do miejsc docelowych związanych $\mathrm{z}$ dziełami literackimi i ich twórcami. Turystyka literacka stanowi więc trwałą część turystyki inspirowanej kulturą.

Należy zaznaczyć, że park Zofiówka ma swoje miejsce w literaturze polskiej. Stanisław Trembecki (1739-1812) był jednym z pierwszych, który uwiecznił go w poemacie Sofijówoka (1804), przyczyniając się tym do rozpowszechnienia sławy o nim w Europie. Poza wspomnianym utworem Trembeckiego pojawia się ona także w dziele innego klasyka polskiej literatury Juliana Ursyna Niemcewicza (Opis). Park był natchnieniem także dla trzech wielkich polskich romantyków - Seweryna Goszczyńskiego (Noc w Zofiówece), Lucjana Siemieńskiego (Ogrody i poeci) i Juliusza Słowackiego (Pamiętnik, Król Ladawy oraz utwór Wacław). Motywy nawiązujące do wspomnień o Zofiówce znaleźć można również w twórczości poetów Bolesława Leśmiana i Jarosława Iwaszkiewicza.

Park Zofiówka jest i może być w turystyce przykładem różnorodnych inspiracji na bardzo wielu płaszczyznach. Trzeba nadmienić, że coraz częściej biura podróży oferują wycieczki specjalistyczne na Ukrainę, w tym do Zofiówki w ramach szlaków kulturowych lub programów opracowywanych na zamówienie, np. dla historyków sztuki krajobrazu bądź dla studentów architektury, historii sztuki, historii czy kierunków filologicznych. Działania 
takie mają duże znaczenie, gdyż pobudzają u młodych ludzi zainteresowanie zarówno turystyką kulturową, jak i opisywanym obiektem.

Innym przykładem przyciągania młodego turysty do Zofiówki jest realizowany od 2008 r. projekt „Polsko-ukraińskiej wymiany młodzieży Narodowego Centrum Kultury". W ramach tego projektu w 2012 r. m.in. odbyło się spotkanie młodzieży ze Staszowa i Tulczyna (staszowski.eu). Poza ciekawym programem pobytu obejmującym spotkania, koncerty oraz zapoznanie się z zabytkami, w tym polskimi z okresu I Rzeczypospolitej, najbardziej ważny wydaje się być bezpośredni kontakt młodych ludzi. Ma on wartość nie do zastąpienia, ponieważ sprzyja poznawaniu kultury obydwu narodów i pomaga $\mathrm{w}$ odchodzeniu od stereotypowego myślenia wzajemnie o sobie. Zofiówka ma wiele walorów turystycznych, które mogą być interesujące tak dla młodych Polaków, jak i Ukraińców.

Park Zofiówka jest więc obiektem, który warto włączać do programów wycieczek na Ukrainę organizowanych przez polskie biura podróży. Wydaje się, że ich organizatorzy będą coraz częściej pracować na coraz bardziej rozwijającym się turystycznym rynku wschodnioeuropejskim. Stąd stoi przed nimi wyzwanie świadomego udziału w kreowaniu turystycznej przygody dla swoich klientów, czyli budowaniu pakietu ofert pod kątem indywidualnych potrzeb turystów.

\section{Wnioski}

Narodowy Dendrologiczny Park Zofiówka w Humaniu na Ukrainie jest istotnym produktem turystycznym, choć dla polskich turystów niszowym, konsumowanym przez homogeniczne grupy pod względem wieku, płci i zainteresowań. W wycieczkach zorganizowanych przez biuro podróży biorą udział głównie grupy tzw. średniokulturowe, które przy prognozach rozwoju turystyki osób starszych, w tym na kierunki wschodnioeuropejskie mają duże szanse na zwielokrotnienie tego ruchu.

W opracowaniu zidentyfikowano różnorodne doświadczenia turystyczne doznawane zarówno przez turystów, jak i organizatorów. Generalnie można je określić jako pozytywne w kontekście poznawczym dla obu grup. W kontekście organizacyjnym nie zawsze mają one taki odcień. Jednak analizowany obiekt ma wiele możliwości, aby oferowany na jego bazie produkt turystyczny rozwijać i wzbogacać tak, żeby był pełnowartościowy i in- 
teresujący dla turystów rodzimych (ukraińskich) oraz zagranicznych (w tym polskich). W świetle zaprezentowanej analizy można stwierdzić, że dziedzictwo kulturowo-przyrodnicze parku Zofiówka sprzyja budowaniu różnorodnych ofert, opartych na zróżnicowanych odcieniach turystyki kulturowej. Mogą one przyciągnąć także młodego turystę.

\section{BIBLIOGRAFIA}

BanaszKieWicz M., 2012, Dialog międzykulturowy w turystyce. Przypadek polsko-rosyjski, Wyd. Uniwersytetu Jagiellońskiego, Kraków.

BucZKOWSKA K., 2008, Turystyka kulturowa, Wyd. AWF w Poznaniu, Poznań.

ChrabAn G., Mitin V., 1990, Istoria osnowanija i stroitelstwa parka, [w:] Dendrologičeskij park Sofijewka. Monografia, N. Kochno (red.), Naukowa Dumka, Kijew.

http://thebestvoyage.ru/unikalnyj-dendropark-sofievka/;15.09.2013.

KAZIMIERCZAK M. (red.), 2012, Jakość życia w kulturowych przestrzeniach podróżowania, AWF w Poznaniu, Poznań.

KOSENKO I., 1990, Ekskursionnym marszrutom, [w:] Dendrologičeskij park Sofijewka. Monografia, N. Kochno (red.), Naukowa Dumka, Kijew.

KOSENKO I., 2003, Dendrologicznyj park Sofiyivka, Humań.

KOSENKO I., 2007, Dendrologicznemu parku "Sofiyivka” HAH Ukrainy - 205 rokiw, www.sofiyivka. org.ua; 15.09.2013.

KOSINSKI W., BYRSKI P., KOWALSKI P., 2008, Dziedzictwo kulturowe a turystyka - kwestie fundamentalne, [w:] Eksploracja przestrzeni historycznej, M.K. Leniartek (red.), Wyd. Wyższej Szkoły Zarządzania, Wrocław.

KOZAK M., BAjDA I., 2002, Odyseja po parku. Sofijewka, OOO Klaksa, Kijew.

KRAKOWIAK B., STASIAK A., WŁODARCZYK B. (red.), 2013, Kultura i turystyka - miejsca spotkań, MSiT, ROT Województwa Łódzkiego, IGMiT UŁ, Łódź.

ŁOJEK J., 1972, Dzieje pięknej Bitynki, Instytut Wydawniczy, PAX, Warszawa.

ŁOJEK J., 1988, Szczęsny Potocki. Dzieje zdrajcy, Wyd. Śląsk, Katowice.

MacCannell D., 2002, Turysta. Nowa teoria klasy próżniaczej, Muza, Warszawa.

Mitin V., 1990, Archiwnyje dokumenty o "Sofijewke", [w:] Dendrologičeskij park Sofijewka. Monografia, N. Kochno (red.), Naukowa Dumka, Kijew.

PIROŻAK-DZIUK I., 2010, Perła wśród stepów - park romantyczno-krajobrazowy Zofiówka jako obiekt krajoznawczo-turystyczny, praca dyplomowa pod kier. J. Wojciechowskiej na Podyplomowym Studium Turystyki, Instytut Geografii Miast i Turyzmu Uniwersytetu Łódzkiego.

PIROŻAK-DZIUK I., WOJCIECHOWSKA J., 2013, The romantic landscape park of Zofiówka in Ukraine as a cultural tourism product forPolish tourists, [w:] Tourism Role in the Regional Economy, vol. IV: Regional Tourism Product - theory and practice, J. Wyrzykowski, J. Marak (eds), University of Business in Wroclaw, Wroclaw.

PODEMSKI K., 2004, Socjologia podróży, Wyd. Naukowe UAM, Poznań.

Prentice R.C., WitT S.F., HAMER C., 1998, Tourism as experience. The case of heritage Parks, "Annals of Tourism Research", 25(1).

staszowski.eu; 14.02.2013. 
URRY J., 1990, The consumption of tourism, "Sociology", 24.

URRY J., 2007, Spojrzenie turysty, PWN, Warszawa.

Walas B., 2001, Marka turystyczna miast i regionów, „Rynek Turystyczny. Pismo Biznesu Turystycznego", 11-12.

WieCZORKIEWICZ A., 2008, Apetyt turysty. O doświadczaniu świata w podróży, Wyd. Universitas, Kraków.

WŁODARCZYK B., KRAKOWIAK B. (red.), 2012, Kultura i turystyka - wspólne korzenie, MSiT, ROT Województwa Łódzkiego, IGMiT UŁ, Łódź.

www. encyklopedia.pwn.pl; 05.02.2013.

www.sofiyivka.org.ua; 15.09.2013.

WYRZYKOWSKI J., 1991, Wstęp i Podsumowanie, [w:] Ocena krajobrazu Polski w aspekcie fizjonomicznym na potrzeby turystyki, J. Wyrzykowski (red.), Wyd. Uniwersytetu Wrocławskiego, Wroclaw.

WYSOKIŃSKI J., 2005, Turystyka czynnikiem przemian wspótczesnego świata, [w:] Turystyka jako dialog kultur, Z. Krawczyk, E. Lewandowskia-Tarasiuk, J.W. Sienkiewicz (red.), Wyższa Szkoła Ekonomiczna w Warszawie, Warszawa.

ZACHARIASZ A., 2006, Zieleń jako współczesny czynnik miastotwórczy ze szczególnym uwzględnieniem roli parków publicznych, Politechnika Krakowska, Kraków. 